\title{
Mageknip, gass og bakterier
}

\author{
Kompaniskapet med våre ørsmå venner bakteriene er en blandet fornøyelse.
}

For flere tiår siden presenterte Lars E. Hanssen en aktuell og velskrevet artikkel i Nordisk Medicin. Med bakgrunn i lang erfaring fra gastroenterologi tok han for seg problemet med ufrivillige tarmlyder hos mennesker. Han viser hvordan produksjon av tarmgass er en viktig del av stoffskiftet og at forstyrrelser i gassproduksjonen kan ledsage en rekke forskjellige sykdommer. Men det er også avhengig av hva vi spiser. Ufrivillige tarmlyder kan være en plage for mange, særlig i forsamlinger eller i selskapslivet.

Lars Hanssen er lege fra Universitetet i Oslo. Han er spesialist i indremedisin, fordøyelsessykdommer og endokrinologi og arbeidet i flere år på Rikshospitalet. Fra 1994 arbeidet han i Statens helsetilsyn, og han var helsedirektør fra 2001. Han er professor i medisin, og fra 2012 direktør for sekretariatet for Vitenskapskomiteen for mattrygghet. Få mennesker har derfor vært så kvalifisert til å skrive om tarmens funksjoner som nettopp han.

I de tre tiårene som er gått siden artikkelen ble skrevet, har det skjedd en revolusjon i forståelsen av tarmlydenes betydning. Hver og en av oss har til enhver tid vel $1 \mathrm{~kg}$ bakterier i tarmen. De står for produksjonen av gass - i tillegg til den luften vi svelger. Hvor mye vi produserer, er avhengig av hva vi spiser. Tarmen inneholder omtrent 1000 ulike typer bakterier, og til sammen utgjør de vesentlig flere celler enn de som bygger opp et helt menneske. Bakteriene har til sammen mer enn hundre ganger så mange gener som mennesket har. Dette mangfoldet er viktig både i dagliglivet og i forbindelse med sykdom.
Forståelsen av normale bakteriers betydning for mennesket har ført til et nytt begrep - «mikrobiomet» eller, med et finere, ord «microbiota». Mye internasjonal forskning beskjeftiger seg nå med våre ørsmå venner som lever i tett kompaniskap med oss. Trolig har disse bakteriene fulgt oss gjennom evolusjonen fra tidenes morgen. Slik har de etter hvert tilpasset seg mennesket og er blitt en nødvendig del av oss.

Man sier vanligvis «jeg» om seg selv, men det er noen som får lov til å betegne seg som «vi» - blant andre konger, journalister, gravide og dessuten folk med bendelorm. Men i lys av nyere forskning spørs det om vi ikke må begrave ordet «jeg» en gang for alle. Vi er alle del av et stort mikrobielt fellesskap, og dette fellesskapet kan altså gi seg ganske høylytte utslag. Tenk på det neste gang du sitter i en forsamling og det kommer buldrende og pipende tarmlyder fra magen din. Da kan du si forklarende til de omkringsittende: «Det er bare mikrobiomet mitt som vil ha et ord med i laget.»

\section{Ole Didrik Lærum}

ole.laerum@gades.uib.no

Ole Didrik Lærum (f. 1940) er professor (adj.) ved Københavns Universitet og professor emeritus ved Universitetet i Bergen.

\section{Borborygmi - Tarmer som larmer}

Lars E Hanssen, dr med, Gastroenterologisk avdeling, Ullevål sykehus, N-Oslo 1. Nordisk Medicin 97; 67-69, 1982.

Intestinal gass kommer dels fra nedsvelget luft, dels fra bakterienes virksomhet i tarmen. Forskjellig mat gir store variasjoner i gassdannelsen. Sykdommer som laktasemangel, coeliaki, ulcus pepticum, achlorhydri, pankreasinsufficiens, galleveislidelser og bakteriell overvekst i tarmen kan føre til øket gassdannelse. Colon irritabile er ikke forbundet med øket gassdannelse, men endret tarmmotorikk. Behandlingen av pasienter med borborygmi og luftplager inkluderer endring til fiberrik kost, regelmessig levesett og mosjon. Det er spesielt viktig med et godt lege-pasient forhold og informasjon om plagenes årsak.

Borborygmi er en gurglende eller boblende lyd som kan høres over tykktarmen - intestinal flatus. Intestinal gass er et tema som opptar mange, og da særlig på en humoristisk måte. Det å bli kvitt tarmgass, enten det skjer ved diskret oppraping, eller ved flatusavgang, er et helt naturligt fenomen, som for de flestes vedkommende ikke skaper noen problemer. En har til og med livnæret seg ved å opptre som «fjertoman», nemlig franskmannen Joseph Pujol som opptrådte på Moulin Rouge i Paris i slutten av forrige århundre (1). Imidlertid finnes det en del pasienter som er alvorlig plaget av luftsmerter samt flatus eller ructus. Disse pasienter kan tildels være vanskelige å behandle.

For dem som ønsker å fordype seg i temaet, har dansken Esben Kirk (2) og nordmannen Finn Askevold (3) vært foregangsmenn.
I internasjonal litteratur er John H Bond (4), Doris Howes Calloway $(5,6,7)$, Michael D Levitt $(8,9$ 10, 11) og FR Steggerda (12) nøkkelnavn. En del av de publiserte resultater er tildels motstridende, og jeg vil holde meg til hovedlinjene.

\section{Registreringsmuligheter}

Enhver er i stand til å registrere sin egen avgang av intestinal gass, enten denne skjer 
som ructus eller flatus. Sammensetningen trenger en instrumenter for å avgjøre, og ved gasskromatografiske metoder kan en bestemme innholdet av hovedgassene $\mathrm{N}_{2}$, $\mathrm{O}_{2}, \mathrm{CO}_{2} \mathrm{H}_{2}$ og $\mathrm{CH}_{4}$. Disse utgjør 99 prosent av innholdet, og de er alle luktfrie. De stoffer i flatus som lukter er skatoler, indoler, $\mathrm{H}_{2} \mathrm{~S}$, samt flyktige fettsyrer og aminer. Kun den første gruppen - hovedgassene - vil bli omtalt. Selvstudier har vist at flatusavgang i gjennomsnitt inntrer $13.6 \pm 5.6$ ganger per dag. Utslippet ligger vanligvis godt under $100 \mathrm{ml} / \mathrm{h}$, og i faste vesentlig lavere. Enorme variasjoner foreligger, men døgnutslippet ligger ofte mellom 400 og $1200 \mathrm{ml}$. Blåser en inn edelgassen argon øverst i tynntarmen (8), kan en med denne metode skylle ut den gass som til enhver tid befinner seg i tarmsystemet, og dette dreier seg om mellom $30 \mathrm{og}$ $200 \mathrm{ml}$.

For å undersøke hvor i tarmsystemet det befinner seg intestinal gass, anvendes røntgenundersøkelse. Oftest er det gass i magesekk og colon, og i omtrent halvparten av tilfellene også i tynntarm.

I de senere år er det utviklet en ny metode, nemlig bestemmelse av tarmgasser i ekspirasjonsluften fra lungene $(10,13)$. Dette bygger på at intestinal gass kan diffundere over i blodet som strømmer gjennom tarmveggen. Denne diffusjonen bestemmes blant annet av differansen i partialtrykk for en bestemt gass i henholdsvis tarmlumen og blod. I enkelte tilfelle, vil partialtrykket i blodet være størst, og da foregår det diffusjon inn i tarmlumen. I tillegg til differansen i parialtrykk, vil også gassenes egenskaper, og egenskaper i tarmveggen spille inn.

Poenget som nyttiggjøres i den nye testen er at $\mathrm{H}_{2}$ og $\mathrm{CH}_{4}$ ikke lages i noen menneskelig celle, kun av bakteriene i tarmkanalen (11). Blodet som kommer til tarmkanalen vil derfor praktisk talt ikke inneholde dem, de taes opp i blodet på grunn av forskjell i partialtrykk, og avgies så ved den motsatte prosess i lungene, og kan så måles i ekspirasjonsluften, nesten på samme måte som en utfører en alkotest.

\section{Fysiologi}

Hvor kommer så all denne gassen fra? Når gassproduksjonen er liten, som i faste, regner en med at opptil halvparten stammer fra nedsvelget luft. En svelger alltid noe luft ved inntak av mat og enda mer ved drikke. Trykket i spiserøret er ofte negativt, og enhver åpning av øvre del medfører at litt luft trekkes inn. Denne føres videre ved svelgning til magesekken. En del av denne luft rapes opp igjen fra magesekken, omtrent på samme måte som laryngektomerte snakker, men en del passerer videre nedover i tarmen.

\section{$\mathbf{N}_{2}$}

Undersøker en flatusinnholdet i faste, finner en store mengder $\mathrm{N}_{2}$ som en antar stammer fra nedsvelget luft. $\mathrm{N}_{2}$ produseres sannsynligvis ikke i tarmkanalen, men siden $\mathrm{N}_{2}$ utgjør en så stor del av innåndingsluften, vil det ha et høyt partialtrykk i blodet. I en del tilfelle vil dette partialtrykket overstige partialtrykket i tarmgass. Dette vil kunne skje når tarmgassen etter et måltid inneholder økende mengder $\mathrm{CO}_{2}$ og $\mathrm{H}_{2}$. Da vil det kunne skje en diffusjon av $\mathrm{N}_{2}$ fra blodet til tarmlumen. $\mathrm{N}_{2}$ i flatus stammer således enten fra nedsvelget luft eller fra diffusjon fra blod. Hoveddelen stammer fra nedsvelget luft.

\section{$\mathbf{O}_{2}$}

Den luften som nedsvelges inneholder også $\mathrm{O}_{2}$. Meget lite av den gjenfinnes i flatus. For det første diffunderer $\mathrm{O}_{2}$ bedre over tarmveggen enn $\mathrm{N}_{2}$, men en hovedfaktor er at $\mathrm{O}_{2}$ bindes aktivt til hemoglobin i blodet. Dette gjør at diffusjonen mellom tarmlumen og blodet lettes. Videre forbrukes $\mathrm{O}_{2}$ av bakteriene i tarmen. Alt dette fører til at $\mathrm{O}_{2}$ konsentrasjonen i flatus ligger meget lavt, og dette skaper muligheter for vekst av anaerobe bakterier, og disse er de beste gassdannere i tarmen.

\section{$\mathrm{CO}_{2}$}

Når magesyren kommer over i tynntarmen frigjøres hormonet sekretin som stimulerer pankreas til å lage bukspytt som er rikt på bikarbonat. Nøytralisering av $1 \mathrm{mmol} \mathrm{HCl}$ danner $22.4 \mathrm{ml} \mathrm{CO}_{2}$, og hvert døgn produseres omlag $100 \mathrm{mmol} \mathrm{HCl}$. Dette gir opphav til $2.21 \mathrm{CO}_{2}$. Tarmen har en enorm evne til å ta opp $\mathrm{CO}_{2}$, dette lettes av enzymet carbonanhydrase i tarmveggen. En antar at det meste av det $\mathrm{CO}_{2}$ som kommer ut med flatus stammer fra bakterier i colon som produserer $\mathrm{Co}_{2}$ og $\mathrm{H}_{2}$ fra ikke nedbrutte karbohydrater.

\section{$\mathrm{H}_{2}$ og $\mathrm{CH}_{4}$}

$\mathrm{H}_{2}$ produseres av tarmbakteriene, og ingen andre steder i kroppen. Bakteriefrie dyr produserer ikke $\mathrm{H}_{2}$. omlag en tredjedel av voksne mennesker huser metanproduserende bakterier i tarmen. Disse forbruker $\mathrm{H}_{2}$ og $\mathrm{Co}_{2}$ for å produsere $\mathrm{CH}_{4}$, og dette vil følgelig senke konsentrasjonen av disse gasser i flatus. Vi vet ikke hvorfor noen mennesker har metanproduserende bakterier og andre ikke. Disse bakterier er imidlertid sterkt anaerobe, og blant de beste gassdannere i tarmen.

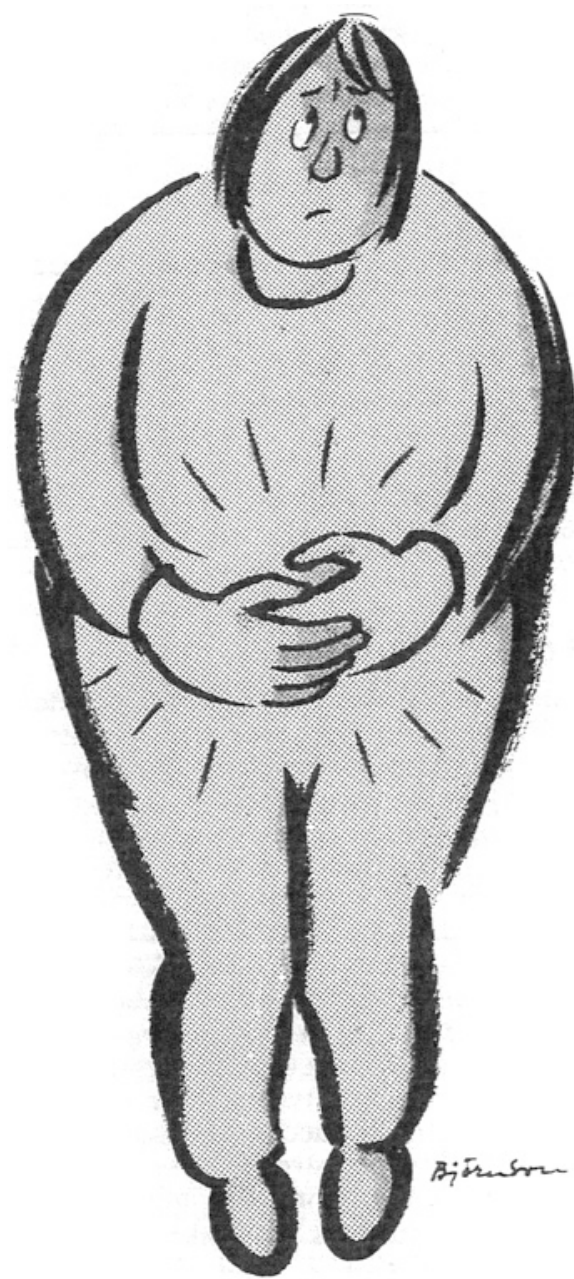

\section{Flatusanalyse}

Når bakteriene i colon produserer mye $\mathrm{H}_{2}$, $\mathrm{Co}_{2}$ og $\mathrm{CH}_{4}$ medfører dette at partialtrykket av de andre gassene, i hovedsak $\mathrm{N}_{2}$ og $\mathrm{O}_{2}$ må gå ned. Derfor vil en analyse av flatus kunne si noe om årsaken til øket flatusavgang (tabell I). Er $\mathrm{N}_{2}$ den dominerende komponent, må det skyldes øket nedsvelgning av luft. Er det derimot $\mathrm{Co}_{2}, \mathrm{H}_{2}$ og eventuelt $\mathrm{CH}_{4}$ som dominerer, taler dette for at økt bakteriell produksjon i tarmen er det viktigste (12).

Hos friske har gass «en slags forkjørsrett» (14). Den har en utrolig evne til å passere væske og matrester. Setter en gass ned i øvre del av tynntarmen, kan den oppsamles som flatus, kanskje allerede etter 30-40 minutter, mens måten jo bruker dager på den samme strekningen.

Hva er det så som bestemmer om det skal bli mye eller lite intestinal gass hos en bestemt person på en bestemt dag? Den naturlige svelgning av mindre mengder luft, aerofagien, kan variere innen vide rammer. Nervøsitet og angst, endret spyttsekresjon 


\begin{tabular}{lr}
\hline Tabell 1 Sammensetning av flatus, prosent \\
\hline $\mathrm{N}_{2}$ & $23-80$ \\
$\mathrm{O}_{2}$ & $0.1-2.3$ \\
$\mathrm{CO}_{2}$ & $5.1-29$ \\
$\mathrm{H}_{2}$ & $0.1-47$ \\
$\mathrm{CH}_{4}$ & $0-26$ \\
\hline
\end{tabular}

kan alle bidra til øket aerofagi. Enhver kjenner til at sammensetningen av kosten spiller en rolle (12).

\section{Kostens sammensetning}

Først skal en være klar over at en del matsorter i seg selv inneholder ganske mye luft. Epler inneholder 20 prosent luft, og ulike souffléer og gratenger bidrar også til mengden nedsvelget luft.

Anderledes stiller det seg med de matsorter som notorisk er gassproduserende ved bakteriernes innvirkning i tarmen, for eksempel belgfruktene (7). De inneholder karbohydrater som ikke kan nedbrytes av kroppens egne enzymsystemer, for eksempel raffinose, verbascose og stachyose. Disse er bygget opp av monosaccharider som i seg selv er absorberbare i øvre del av tynntarmen, men som ikke blir tilgjengelige fordi fordøyelsesvæskene mangler enzymer til å åpne bindingene mellom dem. Disse bindinger åpnes derimot av bakteriene i colon, og monosaccharidene brytes så ned til $\mathrm{Co}_{2}$ og $\mathrm{H}_{2}$. I tillegg til oligosaccharidene vil også cellulose, hemicellulose og lignin komme ufordøyet ned i colon, og i hvert fall de to første bli gjenstand for bakteriell nedbrytning. Vanligvis kommer den økte gassproduksjon i gang først etter fem til seks timer, når substratene når colon.

En har også spekuleret på om svovelholdige forbindelser i for eksempel løk, kunne hemme carbonanhydrasen, og derved minske reabsorpsjonen av $\mathrm{Co}_{2}$. I tillegg til belgfrukter er det vist at hvete og en del frukter er årsak til økt gassdannelse. I hvert fall kan en slå fast at endringer i kostholdet kan medføre enorme endringer i gassutslippet fra rectum (15). Det gjelder som alltid ellers å lytte til sin mage, lære den å kjenne, og så følge de signaler den gir.

\section{Patofysiologi}

Hva hender så om monosaccharider eller oligosaccharider som normalt taes hånd om i tynntarmen, på grunn av sykdom når colon? Svaret er greit - en enorm gassproduksjon. Laktose består av glukose og galaktose, som begge er lett absorberbare i tynntarmen, under forutsetning av at enzymet laktase er tilstede og kan spalte bindingen dem imellom. Er det ikke det, når laktosen colon, spaltes av bakteriene og det produseres $\mathrm{Co}_{2}$ og $\mathrm{H}_{2}$, og produksjonen av den siste kan følges i ekspirasjonsluften (10).

Hos normale kommer det ingen stigning av $\mathrm{H}_{2}$ - i ekspirasjonsluften etter laktose. Også ved bakteriell overvekst i tarmen kan en se $\mathrm{H}_{2}$ stigning i ekspirasjonsluften, siden laktosen møter bakterier før absorpsjonen er fullstendig. En må regne med at slik bakteriell overvekst blir vanligere ettersom mer potente syresekresjonshemmere taes i bruk i ulcusbehandlingen. Også ved shuntoperasjoner på tarmen vil det kunne komme til slik bakteriell overvekst med påfølgende gassproblemer. En har etter slike operasjoner kunnet finne endringer i bakteriefloraen helt ned i colon.

Det er mulig at målinger av $\mathrm{H}_{2} \mathrm{i}$ ekspirasjonsluften kan gi oss ny kunnskap om uklare abdominallidelser som følges av borborygmi, idet dette er et felt hvor mye er uklart. Det er funnet sammenheng mellom gallesten og infisert galle (16), og mellom gallesten og duodenaldivertikler (17). Det skal ikke mye fantasi til for å forestille seg at slike utposninger med tildels gamle matrester kan være et godt reservoar for bakterier, og i noen tilfelle danne utgangspunkt for bakteriell overvekst med gassplager.

Øket syreproduksjon vil betinge at mer $\mathrm{Co}_{2}$ blir produsert ved nøytraliseringen. Pankreasinsuffisiens vil medføre at mer ufordøyd næring vil nå bakteriene $\mathrm{i}$ colon og danne grunnlag for ytterligere gassproduksjon. Et interessant punkt i denne forbindelse er nettopp de bønnesorter som gir mer gassproduksjon, nemlig soya- og limabønner, er spesielt rike på enzymhemmere som blokkerer enzymene i bukspyttet. At også coeliakipasienter med sin forandrede slimhinne og endrede hormonregulering av pankreas, kan få gassproblemer, kan neppe overraske.

\section{Colon irritabile}

Går en igjen nedover tarmsystemet finner en den hyppigste årsak til plager fra intestinel gass i selve colon, nemlig colon irritabile (14). Plagene er vekslende diarré og obstipasjon samt magesmerter. I motsetning til de tidligere nevnte tilstander hvor en øket gassproduksjon synes å være medvirkende, er dette ikke tilfellet ved colon irritabile. Riktignok kan aerofagien - som sees hyppig ved denne lidelse - være meget plagsom, særlig hvis det samtidig foreligger obstipasjon. Selv om obstipasjon i colon kan gjøre at bakteriene der får mer tid på seg til gassproduksjon, så ser det ut til at disse pasienters gass- produksjon er fullstendig normal, både i om-fang og sammensetning. Det er endret tarmmotilitet som skiller disse pasienter fra friske. En ser at om en blåser opp en ballong i tarmen deres, vil de tåle mindre distensjon enn friske før de får vondt. Oftest skyldes hverken knipsmerter eller oppblåstheten og borborygmien en øket eller endret gassproduksjon, det er de endrede motilitetsforhold som lager plagene.

Det hender også hos friske at psykisk stress kan føre til ekstra hurtig tarmpassasje, og da kan en se øket utskillelse av $\mathrm{H}_{2}$ i ekspirasjonsluften, som uttrykk for at ufordøyd matrester når bakteriene $\mathrm{i}$ colon. En må anta at dette også kan skje med irritabel colon pasienter, og utløse akutte episoder. Hos noen vil det også komme symptomer fra hjerteregionen som kan minne om angina pectoris.

\section{Terapi}

Det finnes spesifikk behandling eller dietetiske forholdsregler ved de underliggende sykdommer som laktasemangel, coeliaki, ulcus pepticum, achlorhydri og pankreasinsufficiens. Ved en del av tilstandene vil det være mistanke om bakteriell overvekst, og det kan være fristende å prøve bakteriostatiske eller baktericide midler. Dette anbefales ikke, da en ikke er garantert å slå ut de gassdannende bakteriene, men tvert imot kan gi dem bedre vilkår. Massiv bakteriell overvekst kan være et unntak, men en må ha de pseudomembranøse colitter in mente som mulige komplikasjoner. Det viktigste er å huske på at de fleste luftplager ikke skyldes øket gassproduksjon i det hele tatt, men endrede motilitetsforhold - ofte utløst av laxantiamisbruk.

Et behandlingsprinsipp som har vært anvendt er bruk av overflateaktive stoffer som får små luftblærer til å sprekke, nærmest som en stikker hull på en ballong. Denne behandling bygger på antakelsen at gass er innevevd i slim som hindrer den $\mathrm{i}$ å komme videre. Ved gastroskopi har de nytte idet de letter oversikten, men de nedsætter ikke gassmengden i tarmen. Heller ikke reduserer de flatusmengden, men de kan muligvis nedsette passasjetiden. Det har vært vanskelig å påvise sikker effekt av disse midler ved objektive metoder, men subjektivt finner en del pasienter en lindring.

\section{Kostendring og bulkmidler}

Det viktigste behandlingsprinsipp for disse lidelser er kostendring. Det er vel kjent at vårt moderne kosthold med dets lave innhold av fibre gir hurtig passasje i tynntarmen og obstipasjon i tykktarmen. Setter en kli til 
maten til pasienter med ekstrem hurtig tarmpassasje (mindre enn 1 døgn), øker passasjetiden, og setter en kli til maten til dem som har høy passasjetid, normaliseres denne. Imidlertid inneholder kli en del ikke nedbrytbare fibre som kan gi grobunn for bakterier i colon, slik at tilstanden kan forverres. Det er da rimelig først å anvende andre tilsetningsstoffer, bulkmidler, som også øker faecesmengden og binder vann, og som derved regulerer tarmmotorikken. Når denne så er normalisert, kan en gå over til kli, frukt og andre fiberrike deler av kostholdet. Da vil den økte substratmengden som tilføres colon ikke forbli så lenge som ved obstipasjonen i utgangspunktet. Det er den endrede tarmmotorikken som er nøkkelen til bedring hos den gruppe pasienter som har knipsmerter, oppblåsthet og borborygmi med avvekslende diarré og obstipasjon.

Hvilken plass stoffer som direkte påvirker tarmmotorikken har er vanskelig å fastslå. Det anføres at antikolinergika kan være av betydning. Dette er usikkert, likeledes hvilken plass psykofarmaka har i behandlingen.

\section{Konklusjon}

Først må man lete etter spesifikke grunnsykdommer som laktasemangel, coeliaki, pankreainsufficiens, ulcussykdom, galleveislidelse eller bakteriell overvekst - og så behandle disse. En endring i kostvanene må gjøres. Først reguleres tarmmotorikken med et bulkmiddel, siden økes fiberinnholdet i kosten. Det er også viktig å sørge for god mosjon og regelmessig levesett.

Hvordan skal en så møte disse pasienter som ofte er dypt fortvilte over sine plager?
De har ofte gjennomgått en rekke undersøkelser uten at noe har kunnet vise årsaken. Det er viktig å forklare dem den fysiologiske basis for plagene, vise dem luftsvelgning og informere dem om de ulike matsorters betydning. Det er viktig at den onde sirkel av aerofagi, smerter, angst, gjerne hjertesymptomer og økende aerofagi blir brutt. Det er i denne del av medisinen som ofte ellers psykosomatiske faktorer som kan være nøkkelen til helbredelse. Selv om den farmasøytiske industri har bragt oss både overflateaktive stoffer, antibakterielle midler og motilitetsregulerende stoffer, så er det fremdeles slik at en god trygg pasientlege kontakt med grundig informasjon er det viktigste. Det kan så føre til omlegging av kostholdet, og vil kunne sette patienten selv i stand til å løse sitt problem, gjerne ved øket mosjon og et regelmessig levesett.

\section{Summary}

Intestinal gas is derived partly from swallowed air, and partly from bacterial activity in the intestine. Different food components give rise to widely different amounts of gas. Diseases like lactase deficiency, coeliac disease, peptic ulcer, achlorhydria, pancreatic insufficiency, biliary tract disorders, as well as bacterial overgrowth in the intestine might all lead to increased gas production. The irritabel bowel syndrome is not due to increased gas production, but rather to motility disorders. The treatment of patients with gaseousness includes the change to a diet rich in fibers, as well as physical exercise and a balanced way of life. The importance of a confident doctor-patient relationship is stressed - making the patient able to cope with his gaseousness.
Litteratur

1. Nohain j, Caradec F. Le petomane. Sherbourne Press 1967

2. Kirk E. The quantity and composition of human colonic flatus. Gastroenterology . 12: 782-94, 1949 .

3. Askevold $F$. Investigations on the influence of diet on the quantity and composition of intestinal gas in humans. Scand j Clin Lab Invest 8: 87-94, 1956.

4. Bond JH, Levitt MD. Gaseousness and intestinal gas. Med Clin NA 62: 155-64, 1978

5. Calloway DH. Gas in the alimentary canal, pp 2839-59 in Code CF (ed): Handbook of physiology. vol. 5. Williams \& Williams, Baltimore 1968

6. Calloway DH, Colasito OJ, Mathews RD. Gases produced by human intestinal microFlora. Nature 212: $1238-9,1966$

7. Calloway DH, Murphy EL The use of expired air to measure intesti'1al gas Formation. Ann NY Acad Sci 150: 82-95,1968.

8. Levitt MD. Volume and composition of human intestinal gas determined by means of an intestinal washout technic. New Engl J Med 284 1394-8, 1971.

9. Levitt MD, Bond JH. Flatulence. Ann Rev Med 31: 127-37, 1980 .

10. Levitt M, Donaldson RM. Use of respiratory hydro gen excretion to detect carbohydrate malabsorption. J Lab Clin Med 75: 937-45, 1970.

11. Levitt MD, Ingelfinger FJ. Hydrogen and methane production in man. Ann NY Acad Sci 150: 75-81, 1968

12. Steggerda FR: Gastrointestinal gas following food consumption. Ann NY Acad Sci 150: 57-66, 1968.

13. Bjørneklett $A$, Jenssen E. Measurement of pulmonary hydrogen $\left(\mathrm{H}_{2}\right)$ and $\mathrm{H}_{2}$ diffusion from the small bowel and colon. Scand j Gastroent 15: 817-23, 1980

14. Bárány F. Magknip och väderspänning. Läkartidningen 76: 3172-7. 1979.

15. Sutald LO, Levitt MD. Follow-up of a flatulent patient. Dig Dis Sci 24: 652-4, 1979.

16. Løtveit T, Osnes M, Aune S. Bacteriological studies of common duct bile in patients with gallstone disease and juxtapapillary duodenal diverticula. Scand J Gastroent 13: 93-5, 1978.

17. Osnes M, Løtveit T, Larsen S, Aune S. Duodenal diverticula and their relationship to age sex and biliary calculi. Scand J Gastroent 16: 103-7, 1981. 